\title{
Ben and Me: The Disney Version
}

\author{
Anthony Chase
}

A close reading of the 1953 Disney Studios cartoon featurette, Ben and $M e$, accompanied by an examination of that animated motion picture's literary source within popular juvenile fiction, constitutes the heart of this essay. Additionally, I juxtapose the transformation of fiction into film with the transformation of American society taking place in the background. Thus Disney's adaptation of a tale about the revolutionary origins of American political culture is provided an interpretation which hinges on contextualization.

Since the initial Frankfurt School essays decrying the social effects of popular culture, a nearly unlimited array of interpretive strategies for addressing mass entertainment have emerged, many rather less hostile to the popular arts than the critical theory deployed by Horkheimer and Adorno in their work on the culture industry. ${ }^{1}$ My approach in this essay reflects a desire, first of all, to deal with an instance of popular entertainment on its own terms. It matters little whether we refer to this approach as "close reading" or as criticism which starts from the proposition that every cultural form has its own rules and they help shape the way a work acquires

1 See for example Anthony Chase, "An Obscure Scandal of Consciousness," Yale Journal of Law \& the Humanities, 1 (1988), 114-9 (identifying ideology, "weak-link," means of production, and affirmative critiques, as well as the sociology of culture); Robert Lapsley \& Michael Westlake, Film Theory: An Introduction, (Manchester 1988) (identifying politics, semiotics, psychoanalysis, authorship, narrative, realism, and avant-garde foundations of contemporary film theory). 
social meaning. What counts is that such (at least) initial fidelity to popular art's own rules of the game implicitly helps "challenge descriptions of representation as merely reiterative.",

Next, I attempt to juxtapose a specific work (in this case, the relationship between a film and its fictional source) to a particular historical background: point and field, text and context, an individual work and the notorious larger social canvas within which it constitutes a figure in the landscape, as Jameson and other cultural theorists have described the basic critical operation involved. I have employed the same approach to analysis of individual motion pictures, e.g., Don Siegel's Dirty Harry, ${ }^{3}$ Jean Renoir's The Crime of M. Lange, ${ }^{4}$ and Errol Morris' The Thin Blue Line, ${ }^{5}$ as well as a wide range of "artifacts" from the universe of American legal culture. ${ }^{6}$ The goal, in each case, remains the same: to jump a spark of recognition and insight between the two seemingly disparate poles of art and society.

According to film historian Graeme Turner, movie attendance in the U.S. peaked shortly after the Second World War. By 1953, when Ben and $M e$ was released, almost half of American homes surveyed had at least one television set and the motion picture audience dipped to but half of what it had been in $1946 .{ }^{7}$ In spite of Disney's near total domination of the animated film industry in the 1930s (a golden age when to many, in the view of Ralph Stephen-

2 Pamela Haag \& Dewar MacLeod, "Editor's Introduction," Radical History Review, 66 (Fall 1996), 1.

3 Anthony Chase, "The Strange Romance of 'Dirty Harry' Callahan and Ann Mary Deacon," Radical America 7 (No. 1, 1973) 20.

4 Anthony Chase, "Popular Culture/Popular Justice," in John Denvir, ed., Legal Reelism: Movies as Legal Text (Urbana, Ill., 1996), 133.

5 Anthony Chase, "Avant-Garde, Kitsch, and Law," Nova Law Review, 14 (1990), 549.

6 Anthony Chase, "Lawyers and Popular Culture: A Review of Mass Media Portrayals of American Attorneys," American Bar Foundation Research Journal (1986), 281; Anthony Chase, "Toward A Legal Theory of Popular Culture," Wisconsin Law Review (1986), 527; Anthony Chase, "Historical Reconstruction in Popular Legal and Political Culture," Seton Hall Law Review, 24 (1994), 1969.

7 Graeme Turner, Film as Social Practice (New York 1993), 18. 
son, the cartoon simply meant Walt Disney's work), ${ }^{8}$ Disney Studios emerged from the War with serious financial problems. Leonard Mosley asserts that only "Joseph Rosenberg of the Bank of America had saved them from going out of business." His failure to make money during the War, when so many others in Hollywood had done well, caused Disney to seek out scapegoats. "The bleak situation over money," writes Mosley, "drained him of his dynamic. Misery and worry brought out the worst in him, and he was apt to blame everybody - Jews, blacks, Commies, union workers — for his misfortunes.",

Waiting just around the corner, however, were Disneyland and Davy Crockett; theme park promotion, television, and unprecedented merchandizing operations; ${ }^{10}$ as well as Cinderella, Alice in Wonderland, Peter Pan, Lady and the Tramp, and Sleeping Beauty. In his later years, Disney was fond of reminding his fans that it had all started with a mouse and we should not leave Mickey himself out of the portrait of Disney's ultimate success. "In the seventies," points out Norman Klein, "the permanent rights to Mickey were priced at $\$ 750$ million, more than the total assets of many of the

8 Ralph Stephenson, The Animated Film (New York 1973), 35.

9 Leonard Mosley, Disney's World (Chelsea, Mich. 1990), 207, 263.

10 To be sure, Mickey Mouse merchandizing is as old as Mickey himself; see Harry N. Abrams, Walt Disney's Mickey Mouse Memorabilia: The Vintage Years 1928-1938 (New York 1986). "As an emblem," writes Bevis Hillier in the Introduction to Mickey Mouse Memorabilia, "Mickey has had a potency somewhere between that of the swastika and the Coca-Cola logo in the hierarchy of twentieth-century image-making." Eric Smoodin reports that, in 1948 in Burbank California, Disney was personally presented with Mickey Mouse watch number five million. A photograph of the event published in Time shows Disney, with Manhattan salesman Kay Kamen who had been granted exclusive Mickey Mouse manufacturing rights, "smiling widely as he reads their new contract; in both text and picture, Disney was the happy, rightly rewarded entrepreneur. Disney smiled not only because of the watches that had already been made but because of the products still to come off the assembly line." Eric Smoodin, Animating Culture: Hollywood Cartoons from the Sound Era (New Brunswick, N.J. 1993), 117. See also Richard deCordova, "The Mickey in Macy's Window: Childhood, Consumerism, and Disney Animation," in Eric Smoodin, ed., Disney Discourse: Producing the Magic Kingdom (New York 1994), 203-13 
Fortune 500. One would have to double that figure in the nineties." 11

The early 1950s, as Bob Thomas suggests, marked the turning point in Disney's fortunes. Disneyland, which even in its earliest planning stages included a True-Life Adventureland featuring a "botanical garden with exotic fish and birds,", was inspired in part by Disney's True-Life Adventure films. This documentary film series had appeared in the early 1950 s to be a natural continuation of Disney's wartime informational film production and, significantly, promised to generate much needed revenue during a make or break period in the Studio's financial history. With The Living Desert, their latest True-Life Adventure almost finished, Walt Disney and his brother Roy had an abortive meeting with Howard Hughes to discuss Disney's acquiring RKO films. "With The Living Desert near completion," according to Bob Thomas, "Roy realized that RKO had neither the enthusiasm nor the know-how to sell such an attraction. He established a small sales organization called Buena Vista, after the street where the studio was located." But how was Buena Vista going to sell a seventy-two minute documentary to motion picture exhibitors? "The Living Desert," explains Thomas, "was first booked into the Sutton Theater in New York, along with a cartoon featurette, Ben and Me. It was an immediate success, and Buena Vista added more salesmen and released The Living Desert in a careful, deliberate way throughout the country. Proportionately, it became the biggest profit-maker in Disney history, earning $\$ 4,000,000$ after a production cost of

11 Norman M. Klein, Seven Minutes: The Life and Death of the American Animated Cartoon (New York 1993), 55. For a nutshell economic history of Disney enterprises, see Douglas Gomery, "Disney's Business History: A Reinterpretation," in Eric Smoodin, ed., Disney Discourse: Producing the Magic Kingdom (New York 1994), 71-86. For a sampling of cutting edge theoretical interpretation of the Disney phenomenon, see The Project on Disney, Inside the Mouse: Work and Play at Disney World (Durham, N.C., 1995). For the "official version," see the 25-minute video history of Disney's world: Walt Disney Attractions, Inc., The Walt Disney Story (1994).

12 Bob Thomas, Walt Disney: An American Original (New York 1994), 247. 
$\$ 300,000 . " 13$ By this interesting route did prints of Ben and Me find their way into projection booths in movie houses across the country.

In 1953, that is. It was the year Johnny Lattner won the Heisman Trophy, ${ }^{14}$ Joe Stalin died and a loaf of bread cost six cents. The Korean War ended and Marlon Brando won the Academy Award for On the Waterfront. Queen Elizabeth was crowned, I Love Lucy was America's favorite television show, and HUAC's investigation of Hollywood finally concluded. Simone de Beauvoir's The Second Sex had just been published and, the following year, the Dulles Brothers' CIA would oust Guatemala's legally elected government. The Vietnamese defeated the French at Dienbienphu. Baby boomers were starting school.

Directed by Ham Luske, who had previously succeeded in "making Snow White move with human grace," a tale of origins, a story about how America got started. Specifically, it reveals how the revolutionary stroke of a pen embodied in the Declaration of Independence was the work not of Thomas Jefferson (nor even his friend, Benjamin Franklin) but, instead, a mouse named Amos. (So, as Walt said, it really did "all start with a mouse" - though not, in this instance, the mouse.) It is the bitter winter of 1745 and young Amos relates that in the Colonies, "these were desperate times, jobs were scarce, even for a mouse." As he is almost stepped on and lands unceremoniously in a snowdrift, he

13 Bob Thomas, Walt Disney, at 239. On Disney's True-Life Adventure films, see Robert De Roos, "The Magic Worlds of Walt Disney," (originally published in National Geographic, August 1963, 159-207) in Eric Smoodin, ed., Disney Discourse (New York 1994), 48-68.

14 See W.W. "Pudge" Heffelfinger, This Was Football (New York 1954), 55-6: "How much did football figure in Leahy's life? Well, maybe this anecdote Tim Cohane related will give you an idea: In the fall of 1953, Frank's wife, Floss, fractured her leg running up the stairs in the Leahy home. It was the second day of pre-season practice. 'Gee, honey, I'm awfully sorry,' sympathized the Notre Dame coach. 'Frank,' the missus said, 'it could be a lot worse.' 'What do you mean?' he asked. 'Frank,' she said, 'suppose it had been Johnny Lattner?"'

15 Bob Thomas, Walt Disney, 137. 
adds, "for we were a downtrodden race."16 The "hard times" social context briefly invoked by Sterling Holloway's wonderful voice over narration, in the role of Amos, is quickly undercut, in mid-sentence, by a visual gag. Mice are initially seen as oppressed (downtrodden) but because of their size, which makes them easy for people to step on. The real source of mice politics, however, turns out to be their treatment by cats, or better still, the system of cat and mouse social relations. In fact, in a major departure from Robert Lawson's juvenile fiction of the same name, on which Ben and $M e$ is based, the film's writer, Bill Peet, ${ }^{17}$ and his assistants in story adaptation (including Winston Hibler, who helped write narration for The Living Desert), started "the Disney version," 18 of the American Revolution long before Amos the mouse shows up, cold and starving, on Benjamin Franklin's doorstep.

Disney's Ben and Me adds a prologue to Lawson's book, beginning the story of radical social upheaval with Amos' ancestors struggling against an ancien regime in Europe in the 16th century: a cat regime, to be specific. In one of the first scenes in the film, purportedly taking place in 1568, Amos' remote ancestor, Christopher, seeks refuge in the cellar of a London bakery, only to be denied access to a split open sack of flower by a mean (and hungry looking) cat. Next comes great, great, great grandfather

16 Quotations from Ben and Me in this essay are taken directly from the soundtrack of the videotape version of the film, released in 1989 by Disney Studios, and subsequently sold at Walt Disney stores in shopping malls. It is worth adding this statement, provided at the end of the videotape, which suggests that there are now several versions of Ben and Me: "This program is comprised of the theatrical and television versions of 'Ben and Me,' and is the result of the talents of many creative people at the Walt Disney Studio."

17 Bob Thomas, Walt Disney, 189: "Some of Walt's creative people enjoyed a lively relationship with him. One of those was Bill Peet, who made important story contributions to the cartoon features. Walt once paid him a rare compliment: 'If I were you, Bill, I wouldn't be working for me.' Because of his respect for Peet, Walt tolerated Peet's heated arguments over story matters."

18 This phrase is, of course, borrowed from the title of Richard Schickel, The Disney Version: The Life, Times, Art and Commerce of Walt Disney (New York 1985). 
Jason, "the first real champion of the rights of mice." Amos relates that "during the early 17 th century, the cat population of London had reached alarming proportions and the city was actually threatened by a mouse shortage." At this point, viewers are shown an antiquarian book, opened to the page depicting a cat imprisoned in a large bird cage. Printed beneath this illustration is the inscription: "an ACT demanding that during this present emergency the caging of all CATS be NOW and hereby compulsory under penalty of the STOCKS, MDCXX."19

19 Remarkably, this entire section of Ben and Me is original to the film, and the caged cat illustration is sufficiently like one printed in the 1635 edition of George Wither's A Collection of Emblems, Ancient and Moderne, that I suspect the latter as the actual graphic source used by Disney's crew. See Fred Gettings, The Secret Lore of the Cat (New York 1989), 57: "The 'political' cat symbolism of George Wither in his collection of emblems is nevertheless of the same genre as that used by Langland, though since it is intended as a general political satire it reflects on a less royal, yet no less insidious, corruption and evil. In the relevant engraved roundel Wither shows the cat itself caged, with mice playing fearlessly around. The scene, he tells us, shows that 'When Magistrates confined are, They revell, who were kept in feare.' This cat fitly represents a 'Tyrannous, or wicked Magistrate', for though the mice be a harmful vermin, and the cat their remedy, yet even so 'A ravenous Cat, will punish in the Mouse, The very same Offenses, in the house, Which hee himselfe commits."' Thus Wither's drawing, like the one depicted in Ben and Me, was "pro-mouse," though Wither's was a political cartoon which functioned at the level of metaphor and had human, rather than animal, politics as its target. Of course, that did not make his caged cat drawing itself any less attractive to either Disney's artists or our narrator, Amos mouse. Although anti-cat propaganda certainly conformed to the medieval church's demonization of cats, it ran against the grain of actual cat and mouse ecology since cats had long proved a useful means of controlling the size of rodent populations. Both Robert Darnton in his history of the great cat massacre and William McNeill in his book on plagues and people specifically discuss the relationship between the number of cats and rats in Europe. But neither goes so far as to suggest that the religiously inspired assault on cat populations in the medieval period led directly to a spread of the Black Death. Gary Webster argues that it "would be sheer guesswork to estimate the total impact of rat-linked disease and death. Black rats of the past and brown ones of the present rank so high among global killers that most authorities are content with a general statement. In less than ten centuries, agree experts, diseases involving rats as agents have taken more human lives than all the wars and revolutions ever fought. Plague and typhus do not exhaust the list." Gary Webster, Codfish, Cats, and Civilization (Garden City, N.Y. 1959), 103-4. While pointing out some common misconceptions 
Amos' voice over narration continues, adding further to the family history, "So in 1620 , Jason prepared a petition demanding all cats be caged. Well, this was ignored." Thus Jason is forced to take his family with him aboard ship to the new world. This sequence is remarkably like that which depicts the founding of New England's colonies in Frank Capra's wartime documentary, War Comes to America, a contribution to the Why We Fight series of propaganda films. "Jason soon learned," and Amos recounts, "that the passengers, men and mice, were all in the same boat. They were all fleeing from the persecution and tyranny of the old country. The name of their good ship was the Mayflower ... At last they were free." The screen next is filled with a closeup of one pilgrim's pet kitty who has come along for the cruise. "Meeeooww," purrs the cat, licking his lips menacingly. "Free? Well ..." adds Amos with obvious chagrin. So mice were still not free, not from the seemingly permanent menace of a familiar feline. The revolutionary rhetoric of solidarity is undercut with the "same boat" figurative/literal doubling joke and then the "free at last" aspiration is diluted with the near scriptural invocation: the cat you have with you always.

There is more cat and mouse humor to come. A furry Tom awaits in the Philadelphia bakery whose owners have posted a sign "apprentice wanted," one of the "scarce jobs" for which a mouse

about plague history and observing that "brown rats settled in the cellars of houses, while the domestic rat chose to live in attics close to food supplies," historian Fernand Braudel nevertheless concludes that all "this does not mean that rats, and fleas from rats, did not play a part in spreading disease. On the contrary, a very extensive study ... of the outbreaks of plague at Uelzen in Lower Saxony in 1560-1610 proves that they did." Fernand Braudel, Civilization and Capitalism: The Structures of Everyday Life, 1 (New York 1981), 83-4. Finally, in an aside which Amos would no doubt find appalling, Oswell Blakeston proposes that it "is far better to think of mouse-control work undertaken by cats as something akin to police patrol, a task which often involves grim moments, than to stress the supposed cruelty shown by some unloved grimalkin. The Vicar of St. Mary Redcliffe, Bristol, was in no doubt. To the ecclesiastical cat which had kept his church free of mice, he put up a little stone in his graveyard: "The Church Cat, 1912-1927." Oswell Blakeston, Working Cats (London 1963), 14. 
need not apply, and among Franklin's famous aphorisms Amos locates "a cat in gloves catches no mice," etc. But it is already clear how important cat/mice conflicts are by the time Disney's Ben and Me picks up with Lawson's story of the charming friendship between Amos and a bumbling Benjamin Franklin. Later, when there are "rumors of violence" and "loud talk against the stamp taxes and other outrages," torch wielding demonstrators take to the streets. Caught up in the passion of the moment, Amos (watching events below from high atop a lamp post) slams his a fist into his hand while echoing the slogan, "No taxation without representation!" He immediately loses his balance from the force of the blow and is saved from falling to the ground, head over heels, only because his tail gets caught. There is a call for war, Amos enthusiastically repeats the fist pounding gesture, only to have his bonny patriot's hat fall down over his eyes. The quotidian nature of a mouse's existence - from almost being stepped on to having a tail to coping endlessly with predatory cats - constantly provides a humorous counterpoint to Amos' cocksure radicalism as well as the serious subject matter implicit in any revolutionary insurgency and its history.

Another major alteration of Lawson's book made by Disney's story writers is even more telling. In the Ben and Me cartoon history, Amos serves faithfully as Benjamin Franklin's advisor and confidant. He finally gets fed up, however, with Franklin's practical jokes, like employing Amos for a lightning rod - malicious tricks invariably played out at the mouse's expense. ${ }^{20}$ Amos moves

20 Again, there does appear to be some basis in history for this characterization of Franklin. See Dudley R. Herschbach, "Benjamin Franklin's 'Scientific Amusements,"” Harvard Magazine, 98 (Nov.-Dec. 1995), 40: "Much that [Franklin] did was for the sheer fun of it. For example, one of his favorite toys was an electrical spider; when charged up, it moved around like a real spider. In letters he mentioned the crowds that came to his house to see such things and how he liked to play tricks on them. He had an iron fence and would wire it up to make sparks leap along the rails to excite the onlookers." See also, Patrice Higonnet, "Hating," (reviewing Robert Middlekauf, Benjamin Franklin and his Enemies) London Review of Books (14 Nov. 1996), 16. 
out of Ben's comfortable residence and returns to the old church vestry, behind the paneling, which provided his family their first home in New England. Eventually, when the crisis between colonies and mother country reaches a boiling point and Franklin is beside himself with uncertainty as to what course the people should take, Ben pleads with Amos to return to his side. Amos consents but only on condition that Ben promises to sign a binding contract guaranteeing that he will treat Amos better than in the past. The contract is in Lawson too, in an early chapter titled "The Bargain," but in the book Ben agrees simply to provide Amos' large family (in the church vestry) with cheese, rye bread, and wheat, on a regular basis, and Amos himself with one fur cap, in exchange for Amos' reliable advice and assistance. That's it - the bargain does not reappear in Lawson's account.

But in the film, it comes at the end and plays a much larger role. It becomes the "legal document" which alone can retrieve Amos (with his political savvy) at a time of great national peril. In exchange for Franklin's binding promise to treat Amos with respect, the mouse will once again render service to Franklin, and The Revolution, as a one-mouse brain trust. Amos works all night on the contract and delivers it folded to Franklin the next morning, wrapped around by the mouse's tale as if the ribbon around a barrister's brief. Before Ben can read it, however, Tom Jefferson shows up imploring Franklin to help him finish the historic speech over which he has been wracking his brain. He's stuck and cannot find the words. At this point Amos insists that Ben either read his proposed contract or the mouse is out the door. Franklin raises his magnifying glass to the tiny parchment Amos hands him and begins reading: "When in the course of human events, it becomes necessary ..." "Ben!" cries Jefferson, jumping to his feet, as he immediately picks up where Franklin left off, thrusting his outstretched arms to the sky, dramatically reciting those few incandescent words already familiar to every viewer. The image fades from Ben's hearthside and print shop to the echoing chamber of a revolutionary convocation, and then to a heroically posed classical painting of Jefferson and the Signers. The rest, as they say, is history. 
The problem is why in thundering tarnation Amos would begin his bargain with Franklin with language like "When in the course of human events." Franklin is not King George and all Amos really wants is for Ben to stop using him as an experimental subject along the royal road to Edison and the light bulb. Not only that. Once Jefferson walks in the door, at the moment of rhetorical transposition when Amos' script plays its crucial role, here is Ben's side of the conversation with Tom: "Come in, Red, come in ... Of course, Red ... But Red, I thought it was finished." In a mere fifteen words of dialogue, Franklin refers to Jefferson three times as "Red." Red Skelton and Red Buttons, maybe. Red Schoendienst and Red Grange, yes. But Red Jefferson? Disney Studios thrived on artistic rendering of the familiar, playing out conventions everyone would recognize to the hilt. But who ever heard of a Red Jefferson? It seems odd that this obscure nickname would suddenly be repeated at this moment for no apparent reason. It's just, well ... not Disney.

Reference to Lawson's book not only clears up the mystery but explains what Disney's story writers were up to. In Lawson, "the bargain" between Ben and Amos is not the source for those stirring words which open America's Declaration of Independence. "Red," to be sure, is in Lawson's story but he is not Tom Jefferson. "Red had come up from Virginia," recounts Lawson, "with Mr. Jefferson - in his saddlebag." Red was originally a mouse, and a revolutionary mouse at that! "Scarce had they arrived," says Lawson, "before Red began preaching Revolution to the mice around the Inn stables. He soon had them organized." Red is a revolutionist and political organizer, a "young firebrand" with "radical tendencies," and although prominent Philadelphia mice are a bit taken aback, even "shocked by the violence of his theories," they admire his "eloquence and capacity for leadership." Describing his inspirational polemics delivered to clandestine meetings of radical mouse cadres, Amos relates: "At one of these meetings Red brought forth for discussion a 'Manifesto,' or list of grievances which he felt we mice had suffered at the hands of our master, Man. It began: 'When in the course of human events it becomes necessary for a mouse to dissolve the bands which have 
linked him to his master.' and went on at considerable length."21 From Red to Amos to Ben to Tom: this is Lawson's secret history, a conspiratorial rendition of the founding, a version which ended on the cutting room floor at the studio on Buena Vista. Welcome to Burbank.

What happened? Perhaps even the armchair cultural historian needs but a single clue: Robert Lawson's Ben and Me was written and published in 1939. What took place during the fourteen years separating Lawson's children's book from the Disney version? No one has put it more clearly and concisely than world-systems theorist, Immanuel Wallerstein. He suggests that the conclusion of WWII altered the basic premises of the previous period's historical and political structure:

First, in terms of the interstate system, the US emerged as the uncontested hegemonic power ... furthermore, there were no longer any significant 'rightist' governments among the core states. On the world scene, the US quickly shifted therefore from being 'left of center' to being the leader of a 'free world' alliance against the world left, now dubbed 'communist totalitarianism.'

Wallerstein also indicates that 1945 marked the beginning of a long economic upswing in the capitalist west which dramatically reduced internal social tensions. "The elimination of the need for a 'popular front' alliance internationally," he observes, "ended all need for it internally in the U.S. Quite the contrary: the period after 1945 was one of sharp suppression of left forces in US society.",22 Thus the journey from Lawson to Disney, from 1939 to 1953,

21 Robert Lawson, Ben and Me (Boston 1939, 1988), 67-8.

22 Immanuel Wallerstein, "The USA in the World Today," in The Politics of the World-Economy (New York 1984), 71-2. 
marked the transition from "popular front",23 to McCarthyism, an alarmingly abrupt transformation of national culture and ideology which goes a long way toward explaining the different versions of Ben and Me.

Is it fair to call Lawson's vision of revolution a "popular front" approach? Beyond presenting the Declaration of Independence as a radical manifesto smuggled into the hands of the people at the top by a firebrand mouse named Red, whose violent theories shock even those who would borrow from his revolutionary rhetoric, there's still more. When Red discovers that Franklin and Jefferson have purloined his oratory, he complains about their "theft of his labors," 24 a familiar left-wing charge against capitalism in general. Following his contribution to the American Revolution, Red joins Amos in France for a life and death struggle against "The White Mice of Versailles," 25 thereby demonstrating international class solidarity. Rather than cats vs. mice, in Lawson it is mice vs. mice, the rodents dividing sharply amongst themselves along class lines. "Patricians!" snorts Red, condemning his new adversaries, "Aristocrats! Oppressors!"26 A Bolshevik at heart, Lenin of the mousey

23 See Eric Hobsbawm, The Age of Extremes (New York 1994), 147-8: "Essentially the strategy put forward (in conjunction with Stalin) by the Communist International (which had chosen as its new General Secretary George Dimitrov, a Bulgarian whose brave public defiance of the Nazi authorities in the Reichstag fire trial of 1933 had electrified anti-fascists everywhere) was one of concentric circles. The united forces of labour (the 'United Front') would form the foundation of a wider electoral and political alliance with democrats and liberals (the 'Popular Front'). Beyond this, as the advance of Germany continued, the communists envisaged an even wider extension into a 'National Front' of all who, irrespective of ideology and political beliefs, regarded fascism (or the Axis powers) as the primary danger. This extension of the anti-fascist alliance beyond the political Centre to the Right - the French communists' 'hand stretched out to the Catholics', or the British ones' readiness to embrace the notoriously red-baiting Winston Churchill - met with more resistance, on the traditional Left until the logic of war finally imposed it."

24 Robert Lawson, Ben and Me, 69.

25 Robert Lawson, Ben and Me, 89.

26 Robert Lawson, Ben and Me, 88. 
set, ${ }^{27}$ Red declares that the "downtrodden Slum Mice and Sewer Rats of Paris are ripe for Revolution ... All they lack is a leader. I will be that leader." 28 Red even recruits Russian mice to join the struggle against reaction but, Lawson records, "Alas for Red's faith in the proletariat! At the first site of the lavish refreshments spread out in the adjoining rooms his fickle Revolutionists dropped their weapons and rushed for the food.",29

So Lawson, too, deploys ironic humor to distance himself from left-wing utopianism, demonstrating in the process his own residual cynicism about the staying power of radical political elan and authentic revolutionary commitment. Nevertheless, there is no mistaking the critical distance between Lawson and Disney, between the thirties and the fifties of America's 20th century. The contradiction is amplified by an additional contrast, that between Northeast and Southwest, between Rustbelt and Sunbelt, or in Carl Oglesby's formulation between "Yankees" and "Cowboys," within recent American political and cultural history. Popularized in the 1970s by Kirkpatrick Sale in his best-selling book, Power Shift, ${ }^{30}$ this critique of postwar American social and economic transformation is, perhaps, most fully developed in the writing of Mike Davis:

I describe this industrial revolution in the old hinterland as 'taxled' because federal fiscal transfers, secured by the historically

27 See Orlando Figes, A People's Tragedy (London 1996), 150: "Lenin's strident prose style, which was imitated by all the great dictators and revolutionaries of the twentieth century, emerged for the first time in What Is To Be Done? It had a barking, military rhythm, a manic violence and decisiveness, with cumulative cadences of action or abuse." See also Eric Hobsbawm, "Out of the Great Dark Whale," London Review of Books (31 Oct 1996), 3: "Figes's unsympathetic portrait of Lenin, even allowing for the debt to Volkogonov's muck-raking biography, probably reflects the post-Soviet mood, though it also corresponds to some contemporary impressions."

28 Robert Lawson, Ben and $\mathrm{Me}, 89$.

29 Robert Lawson, Ben and Me, 100.

30 Kirkpatrick Sale, Power Shift: The Rise of the Southern Rim and its Challenge to the Eastern Establishment (New York 1975). 
disproportionate congressional power of the South and West, were the prime movers in the creation of the Sunbelt. Thus in California, Washington, Texas and Florida, military spending sponsored the rise of aerospace and electronic industry complexes, while oil depletion allowances and agricultural credits rationalized the regional primary sectors and encouraged downstream diversification in oil technology and agricultural processing/merchandising. Immense long-term expenditures on highways, water projects and natural gas pipelines laid the basis for profligate metropolitan development in the desert West. ${ }^{31}$

And out of that desert West, after the War, came not only Disney's Living Desert and Ben and Me, Disneyland and station wagon living, but Nixon and Reagan, Watergate and Iran-contra, and the whole new tilt in American political life. ${ }^{32}$ Davis rightly sees this transformation anchored in an actual economic reversal, a volteface in the balance of power which reigned from the Civil War to World War II, a dramatic alteration in who gets what inevitably arising from seismic dislocation within the real bases of power. Thus it is no accident that since that fateful day in Dallas in 1963, America has elected two presidents from California, two from Texas, and one each from Georgia and Arkansas: tip of the iceberg of a power shift, indeed. The contrast between Harvard's and JFK's Boston, where Lawson's Ben and Me was published by Little, Brown \& Company in 1939, and Disney's Southern California in the $1950 \mathrm{~s}$, base of operations for a genuinely right-wing Rising Tide, could not be greater.

31 Mike Davis, Prisoners of the American Dream (London 1986), 194.

32 Is it fair to lump Disney in with politicians like Nixon and Reagan, or their underlings like Colson and Meese? See Campbell McGrath, "Two Sections from The Bob Hope Poem," TriQuarterly, 94 (Fall 1995), 174: "What is it with this generation of white men from Southern California - the highway builders and golf players, the oil barons, the water hoarders, the dream merchants, the oligarchs, the last frontiersmen, Uncle Walt and the Duke, Nixon's Committee of 100 and the whole Reagan crew, who willingly testified to their fondness for none but former Marines and self-made millionaires like themselves, though it proved so hard to assert anything categorical under oath." See also Anthony Chase, "Unwritten Constitution, Invisible Government," 18 Nova Law Review (1994), 1703. 
Rumors about Disney, "assisting in setting up the blacklist," according to Norman Klein, "began the saga of anti-Disney lore about Disney as reactionary - and remains a sore point in animators' biographies and animation histories even today." 33 Eric Smoodin fills in much of the detail to which Klein refers and he concludes that film historians and critics have often pictured Hoover's FBI as antagonistic to liberal or communist writers and filmmakers while "in a sympathetic relationship with such rightwing figures as John Wayne and Walt Disney. But," concludes Smoodin, "the Bureau's information on Disney shows that these relationships were never so simple ... He was a chief propagandist but also a producer of potentially subversive movies." ${ }^{, 34}$ The subversive potential in Robert Lawson's Ben and $M e$, at any rate, was considerable and it is precisely his more sympathetic view of revolution - a vision which might have permitted, for example, a very different American reaction to Vietnamese nationalism ${ }^{35}-$

33 Norman Klein, 7 Minutes, 184. On the cartoonist strike of 1941 and the popular front in animation, see Holly Allen \& Michael Denning, "The Cartoonists' Front," South Atlantic Quarterly, 92 (Winter 1993), 89.

34 Eric Smoodin, Animating Culture, 167-8.

35 See Gabriel Kolko, Anatomy of a War: Vietnam, the United States, and the Modern Historical Experience (New York 1985); William A. Williams, ed., American in Vietnam: A Documentary History (Garden City 1985); Tom Wells, The War Within: America's Battle Over Vietnam (Berkeley 1994). How much potential or real room was there, in culture and politics, for the emergence of an alternative vision of America's relationship to revolution, whether in France, Russia, Vietnam or anywhere else? Consider, William A. Williams, "American Intervention in Russia 1917-1920," in History as a Way of Learning (New York 1973), 99: "Despite their concern to defeat Germany and to check Japan in the Far East, American leaders repeatedly refused to explore the possibility of attaining those objectives through collaboration with the Bolsheviks. This was not a hypothetical alternative. In spite of their theoretical doctrine, and the suspicion and hesitance it created in their minds, the Bolshevik leaders made persistent efforts to establish such cooperation. This flexibility created one of those turning points in history at which no one turned. The primary reason this opportunity was never exploited was because American leaders proved in action to be more doctrinaire and ideologically absolutist than the Bolsheviks. What might have been can never be known." The same, of course, can be said about the role of the United States in Vietnamese history. 
that was so carefully extracted from the Disney version. The real evidence of Disney's politics is not in an FBI file but in the images he put on the screen. ${ }^{36}$ If you can dream it or imagine it, Disney used to say, you can make it come true. But Disney Studios simply could not imagine a little American mouse named Red. We have all paid a price for that lack of imagination.

36 And the case here, I suspect, if more complicated to make, is even stronger than one founded in the detail of Disney's personal political career. The inherently indeterminate nature of "culture studies," however, if not the culture being studied, leaves room for debate even with regard to the politics of Disney cartoons and comics. Compare, for example, Ariel Dorfman \& Armand Mattelart, How to Read Donald Duck (1991) with David Wagner, "Donald Duck: An Interview," Radical America, 1 (1973), 7. Indeed, Disney's Ben and Me is itself subject to different kinds of interpretation. The film includes a rather sophisticated framing device with sound and visual montage employed to bring the viewer first into the mouse version of history (at the beginning of the film) and then back out of that narrative (at the end of the film) via the commentary of a (non-mouse) historical site tour guide, the latter obviously betraying either sheer ignorance of the facts or an effort to suppress historical truth. It would not take a deconstructionist critic long to locate in Ben and Me, or, more precisely, in the cartoon's juxtaposition of "real" (i.e., mouse) history and official history, a deep suspicion of grand historical narrative as well as a profound appreciation of the fact that history is never more than a hegemonic construction of myth and ideology. Ben and $\mathrm{Me}$, in this view, is not so much about the foundation of the Republic as it is about the dissolution of discourse - an inevitable relativism of meaning which undermines all claims to objective knowledge, and so forth, i.e., postmodern Disney. 